\section{Factors associated with secondary hyperparathyroidism in premenopausal women undergoing Roux-en-Y gastric bypass for the treatment of obesity}

\author{
Fatores associados com hiperparatireoidismo secundário \\ em mulheres na pré-menopausa submetidas a bypass \\ gástrico em Y de Roux para tratamento de obesidade
}

Renata Simões de Vasconcelos', Maíra Viégas' ', Thyciara Fontenele Marques', Erik Trovão Diniz', Cynthia Salgado Lucena', José Bezerra Câmara Neto², Francisco Bandeira'

\begin{abstract}
Objective: To evaluate bone metabolism, bone density (BMD) and vertebral fractures in morbidly obese individuals. Subjects and methods: Case series of 29 premenopausal obese patients, 15 of whom had been submitted to bariatric surgery. Serum calcium, albumin, PTH and 25-hydroxy vitamin $\mathrm{D}$ (25OHD) were measured as well as bone densitometry of the lumbar spine and proximal femur, and lateral spine x-rays. Results: High parathyroid hormone (PTH) levels were recorded in $46.6 \%$ of the surgical patients and in $21.4 \%$ of the non-surgical patients $(p=0.245) ; 26.7 \%$ of the former and $28.6 \%$ of the latter revealed levels $250 \mathrm{HD} \leq 30 \mathrm{ng} / \mathrm{mL}(p=1.000)$. Calcium intake was higher in the surgical group $(p=0.004)$ along with lower serum calcium concentrations $(p=0.019)$. There were no significant differences in bone mineral density (BMD) or in the prevalence of vertebral fractures between groups. Conclusion: In premenopausal women undergoing Roux-en-Y gastric bypass there is important intestinal calcium mal absorption which seems to be the main factor causing secondary hyperparathyroidism. Arq Bras Endocrinol Metab. 2010;54(2):233-8
\end{abstract}

Keywords

Bone mass; fracture; bone disease; bone remodeling; bariatric surgery

\section{RESUMO}

Objetivo: Avaliar o metabolismo ósseo, a densidade mineral óssea (DMO) e as fraturas vertebrais em obesos mórbidos. Sujeitos e métodos: Série de casos de 29 mulheres obesas e na pré-menopausa das quais 15 foram submetidas à cirurgia bariátrica. Realizadas dosagem sérica de cálcio, albumina, hormônio da paratireoide (PTH) e 25-hidróxi-vitamina D (250HD), densitometria óssea de coluna lombar e fêmur e radiografia de coluna vertebral. Resultados: Os níveis de PTH estavam elevados em $46,6 \%$ das pacientes operadas e em $21,4 \%$ das pacientes não operadas $(p=0,245) ; 26,7 \%$ das operadas e $28,6 \%$ das não operadas apresentavam $250 \mathrm{HD} \leq 30 \mathrm{ng} / \mathrm{mL}$ $(p=1,000)$. A ingestão de cálcio foi maior no grupo operado $(p=0,004)$ e o cálcio sérico foi menor neste grupo $(p=0,019)$. Não houve diferenças significativas na densidade mineral óssea (DMO) e na prevalência de fraturas vertebrais entre os grupos. Conclusão: Em mulheres na pré-menopausa, submetidas ao bypass gástrico em Y de Roux, há considerável má absorção intestinal de cálcio, que parece ser o principal fator causador do hiperparatireoidismo secundário. Arq Bras Endocrinol Metab. 2010;54(2):233-8

Descritores

Massa óssea; fratura; doença óssea; remodelação óssea; cirurgia bariátrica
Divisão de Endocrinologia e Diabetes, Hospital Agamenon Magalhães, Sistema Único de Saúde (SUS), Universidade do Estado de Pernambuco (UPE), Recife, PE, Brasil 2 Divisão de Cirurgia Geral, Hospital Agamenon Magalhães, SUS/UPE, Recife, PE, Brasil

Correspondence to: Francisco Bandeira Av. Rui Barbosa, 1435 52050-450 - Recife, PE, Brasil fbandeira@gmail.com

Received on Nov/15/2009 Accepted on Feb/9/2010 


\section{INTRODUCTION}

$\mathrm{O}$ besity is currently considered a global epidemic and is regarded as one of the most important risk factors for a number of diseases such as type 2 diabetes mellitus, dyslipidemia, sleep apnea, gall bladder diseases, coronary diseases, hypertension, musculoskeletal disorders, cancer and psychosocial disturbances $(1,2)$. Recent studies have demonstrated that body mass index (BMI) is in itself a strong predictor of overall mortality (3).

Despite the tendency to associate morbid obesity with the treatment of metabolic bone diseases, vitamin $\mathrm{D}$ and calcium deficiencies and high levels of parathyroid hormone (PTH) are common findings among the obese population thereby increasing the risk of bone loss (4-9). The mechanism responsible for these abnormalities in the morbidly obese remains uncertain, although evidence points to the storage of vitamin $\mathrm{D}$ in fatty tissue, resulting in a reduction in its bioavailability $(4,9,10)$.

In patients submitted to bariatric surgery, a number of studies have demonstrated an increased risk of secondary hyperparathyroidism (SHPT) and reduced bone mineral density (BMD) (2,4,11-13). Metabolic alterations have been reported just eight weeks after bariatric surgery and the lack of an efficient supplementation of calcium, vitamin $\mathrm{D}$, magnesium, vitamin B12 and proteins may cause bone loss, resulting in fractures and other adverse effects $(4,11,13-17)$.

There appears to be a strong correlation between the percentage of bone loss and the rate of weight loss. After bariatric surgery many patients lose weight very quickly. This abrupt loss of weight combined with a restricted oral intake, reduced calcium absorption and a vitamin $\mathrm{D}$ deficiency are factors that put patients at high risk for the rapid development of metabolic bone diseases $(2,8,18-21)$.

The aim of the present study was to evaluate alterations in bone turnover markers and bone mass as well as the presence of vertebral spinal fractures in morbidly obese patients divided into two cohorts, one of which had undergone bariatric surgery.

\section{SUBJECTS AND METHODS}

A series of 29 premenopausal women over the age of 18 years, 15 of whom had undergone bariatric surgery and 14 who were obese, with a BMI $\geq 40 \mathrm{~kg} / \mathrm{m}^{2}$ or $\geq 35 \mathrm{~kg} / \mathrm{m}^{2}$ associated with comorbidities, and who had not undergone surgery. The patients were recruited from the Endocrine and General Surgery Departments at Agamenon Magalhães Hospital. All patients agreed to participate in the study after providing the informed consent. The study was approved by the Agamenon Magalhães Hospital Ethics Committee.

Fifteen patients were submitted to a Roux-en-Y gastric bypass (Capella technique), carried out with a gastric camera with a capacity of approximately $30 \mathrm{~mL}$ and a feed cable of $150 \mathrm{~cm}$. All the operations were performed between September 2007 and October 2008. Information regarding weight, height and BMI prior to bariatric surgery was analyzed from the patients' medical records.

Serum alkaline phosphatase (AP), calcium, magnesium, phosphorus, albumin and 24-hour urinary calcium excretion were determined using the VITROS 950 system (Johnson-Johnson Company). Serum PTH was measured by the immunometric two-site chemiluminescence method, with intra-assay and inter-assay coefficients of variation of $4.2 \%-5.7 \%$ and $6.3 \%-6.8 \%$, respectively. Serum 25 -hydroxy vitamin D (25OHD) was measured by high performance chromatographic liquid method, with intra-assay and inter-assay coefficients of variation of $8.4 \%$ and $12.9 \%$, respectively.

Bone mineral density was determined by Dual Energy X-ray Absorptiometry (Lunar Corporation Madison, Wisconsin, USA), at the following skeletal sites: antero-posterior lumbar spine (LS) L1 to L4, proximal femur, including the femoral neck and total femur, the results being expressed in $\mathrm{g} / \mathrm{cm}^{2}$ and T-score. The in vivo precision error of the equipment used in the study is expressed as a percentage coefficient of variation $(\% \mathrm{CV}=$ standard deviation, mean BMD of repeated determinations) and was $0.9 \%$ for the lumbar spine and $1.2 \%$ for the femoral neck.

Lateral spine $\mathrm{x}$-rays were evaluated by a radiologist using internationally adopted criteria to define morphometric fractures (the Genant semiquantitative method), using the anterior, medium and posterior measurements of the height of the vertebral bodies T4 to L5: grade I: "mild", compression fracture with a loss of anterior vertebral height of more than $20 \%$ and less than 25\%; grade II: "moderate", compression fracture with a loss of anterior vertebral height of more than $25 \%$ and less than $40 \%$, or a deformity of between $20 \%$ and $25 \%$ affecting the anterior or median vertebral height; and grade III: "severe", compression fracture with extreme deformity and loss of volume or a projected area of more than $40 \%$ in relation to the adjacent unfractured vertebra. 
Data analysis provided the absolute and percentage distributions and statistical measurements: mean and standard deviation (techniques of descriptive statistics) and statistical tests: the Pearson chi-square test, or the Fisher Exact test when conditions to apply the chi-square test were not met, and the Student t-test with equal or unequal variations. The Levene f-test was applied to verify the equality of variance hypothesis.

Statistical calculations were carried out with SPSS (Statistical Package for the Social Sciences) version 15. The margin of error employed in the analysis of the statistical tests was $5.0 \%$.

\section{RESULTS}

Table 1 illustrates the clinical characteristics and mean intake of calcium, vitamin D and vitamin B12 in the two groups.

Table 1. Clinical characteristics of study patients

\begin{tabular}{|c|c|c|c|}
\hline Variable & $\begin{array}{l}\text { Submitted to } \\
\text { bariatric } \\
\text { surgery } \\
(n=15) \\
\text { Mean } \pm \text { SD }\end{array}$ & $\begin{array}{l}\text { Not submitted } \\
\text { to bariatric } \\
\text { surgery } \\
(n=14) \\
\text { Mean } \pm \text { SD }\end{array}$ & $p$ value \\
\hline Age: (years) & $35.07 \pm 7.36$ & $34.71 \pm 8.09$ & $\mathrm{p}^{(1)}=0.903$ \\
\hline Height: (cm) & $163.60 \pm 4.73$ & $160.14 \pm 6.24$ & $p^{(1)}=0.103$ \\
\hline Preoperative weight: (kg) & $123.07 \pm 10.94$ & $114.35 \pm 15.94$ & $p^{(1)}=0.096$ \\
\hline Postoperative weight: (kg) & $82.31 \pm 13.06$ & ** & $\star \star$ \\
\hline Weight loss: (kg) & $40.49 \pm 6.61$ & ** & ** \\
\hline Preoperative BMI: (kg/m²) & $46.08 \pm 5.17$ & $44.59 \pm 5.93$ & $\mathrm{p}^{(1)}=0.477$ \\
\hline Postoperative BMI: (kg/m²) & $30.81 \pm 5.30$ & ** & ** \\
\hline $\begin{array}{l}\text { Time elapsed since surgery: } \\
\text { (months) }\end{array}$ & $12.53 \pm 5.32$ & ** & $\star \star$ \\
\hline $\begin{array}{l}\text { Calcium intake - total: } \\
\text { (mg/day) }\end{array}$ & $824.20 \pm 513.11$ & $328.86 \pm 301.03$ & $p^{(1)}=0.004^{*}$ \\
\hline $\begin{array}{l}\text { Calcium intake - diet: } \\
\text { (mg/day) }\end{array}$ & $623.33 \pm 440.09$ & $328.86 \pm 301.03$ & $\mathrm{p}^{(1)}=0.046^{*}$ \\
\hline $\begin{array}{l}\text { Calcium intake - } \\
\text { supplement: (mg/day) }\end{array}$ & $200.87 \pm 142.25$ & $0.00 \pm 0.00$ & $\mathrm{p}^{(2)}<0.001^{*}$ \\
\hline $\begin{array}{l}\text { Vitamin D supplement: } \\
\text { (U/day) }\end{array}$ & $533.33 \pm 445.08$ & $0.00 \pm 0.00$ & $\mathrm{p}^{(2)}<0.001^{*}$ \\
\hline $\begin{array}{l}\text { Vitamin B12 supplement: } \\
\text { (mcg/day) }\end{array}$ & $7.00 \pm 5.57$ & $0.00 \pm 0.00$ & $\mathrm{p}^{(2)}<0.001^{*}$ \\
\hline DM: n(\%) & $1(6.7)$ & $3(21.4)$ & $\mathrm{p}^{(3)}=0.330$ \\
\hline SAH: $n(\%)$ & $7(46.7)$ & $11(78.6)$ & $\mathrm{p}^{(4)}=0.077$ \\
\hline $\begin{array}{l}\text { Regular menstrual cycle: } \\
\mathrm{n}(\%)\end{array}$ & $15(100.0)$ & $11(78.6)$ & $p^{(3)}=0.100$ \\
\hline
\end{tabular}

$\left.{ }^{*}\right)$ : significant difference of $5.0 \%$. Obs.: Mean \pm SD signifies mean and standard deviation. $\left(^{* \star}\right)$ : Not possible to calculate due to the existence of information on only one group. (1): Using the Student t-test with equal variances. (2): Using the Student t-test with unequal variances. (3): Using the Fisher exact test. (4): Using the Pearson chi-square test. BMI: body mineral index. DM: diabetes mellitus. SAH: systemic arterial hypertension.
Serum calcium was within normal limits in all patients in both groups.

Serum magnesium was below normal in $13.3 \%$ of the patients submitted to surgery and normal in those not submitted to surgery. Serum alkaline phosphatase was high in $6.7 \%$ of the patients submitted to surgery as opposed to the normal levels of those who had not undergone surgery.

Serum PTH levels were higher than normal in 46.6\% of the surgical patients and in $21.4 \%$ of the non-surgical patients ( $\mathrm{p}=0.245$ ). Serum $25 \mathrm{OHD}$ was $30 \mathrm{ng} / \mathrm{mL}$ or less in $26.7 \%$ of the former and $28.6 \%$ of the latter $(\mathrm{p}=$ 1.000 ), while $13.3 \%$ of the surgery group and $7.1 \%$, of the non-surgery group had levels of $20 \mathrm{ng} / \mathrm{mL}$ or less and these differences were not statistically significant $(\mathrm{p}=1.000)($ Table 2, Figure 1).

Table 2. Laboratory and bone mineral density data from study patients

\begin{tabular}{|c|c|c|c|}
\hline Variable & $\begin{array}{l}\text { Submitted to } \\
\text { bariatric } \\
\text { surgery } \\
(n=15) \\
\text { Mean } \pm \text { SD }\end{array}$ & $\begin{array}{l}\text { Not submitted } \\
\text { to bariatric } \\
\text { surgery } \\
(n=14) \\
\text { Mean } \pm \text { SD }\end{array}$ & $p$ value \\
\hline $\begin{array}{l}\text { Serum calcium: } \\
\text { (RV: 8.4-10.2 mg/dL) }\end{array}$ & $9.33 \pm 0.21$ & $9.16 \pm 0.14$ & $\mathrm{p}^{(1)}=0.019^{*}$ \\
\hline $\begin{array}{l}\text { Serum magnesium: } \\
\text { (RV: } 1.6-2.3 \mathrm{mg} / \mathrm{dL})\end{array}$ & $1.80 \pm 0.20$ & $1.84 \pm 0.15$ & $p^{(2)}=0.589$ \\
\hline $\begin{array}{l}\text { Serum phosphorus: } \\
\text { (RV: } 2.5-4.5 \mathrm{mg} / \mathrm{dL} \text { ) }\end{array}$ & $4.25 \pm 0.31$ & $3.69 \pm 0.52$ & $p^{(2)}=0.001^{*}$ \\
\hline $\begin{array}{l}\text { Alkaline phosphatase: } \\
\text { (RV: } 38-126 \mathrm{U} / \mathrm{L} \text { ) }\end{array}$ & $87.07 \pm 33.51$ & $87.29 \pm 18.50$ & $\mathrm{p}^{(2)}=0.983$ \\
\hline $\begin{array}{l}\text { 250HD: } \\
\text { (RV: } 30-60 \mathrm{ng} / \mathrm{mL} \text { ) }\end{array}$ & $37.07 \pm 10.64$ & $33.64 \pm 8.88$ & $\mathrm{p}^{(2)}=0.357$ \\
\hline $\begin{array}{l}\text { PTH: } \\
\text { (RV: } 12-65 \mathrm{pg} / \mathrm{mL} \text { ) }\end{array}$ & $63.14 \pm 24.95$ & $52.63 \pm 19.22$ & $p^{(2)}=0.217$ \\
\hline $\begin{array}{l}\text { High PTH levels: } \\
\text { (n. \%) }\end{array}$ & $7(46.7)$ & $3(21.4)$ & $\mathrm{p}^{(3)}=0.245$ \\
\hline $\begin{array}{l}\text { Serum creatinine: } \\
\text { (RV: } 0.7-1.2 \mathrm{mg} / \mathrm{mL})\end{array}$ & $0.74 \pm 0.11$ & $0.71 \pm 0.11$ & $p^{(2)}=0.413$ \\
\hline $\begin{array}{l}\text { 24-hour urinary } \\
\text { calcium: (100-300 } \\
\text { mg/day) }\end{array}$ & $202.57 \pm 127.71$ & $176.07 \pm 115.47$ & $p^{(2)}=0.564$ \\
\hline \multicolumn{4}{|l|}{ BMD: $\left(\mathrm{g} / \mathrm{cm}^{2}\right)$} \\
\hline L1-L4 & $1264.53 \pm 129.71$ & $1201.50 \pm 133.79$ & $p^{(2)}=0.209$ \\
\hline Femoral neck & $1078.20 \pm 106.86$ & $1151.79 \pm 162.85$ & $p^{(2)}=0.159$ \\
\hline Total femur & $1120.27 \pm 149.51$ & $1206.00 \pm 146.00$ & $p^{(2)}=0.130$ \\
\hline $\begin{array}{l}\text { Vertebral fracture: } \\
\text { (n. \%) }\end{array}$ & $2(13.3)$ & $1(7.14)$ & $\mathrm{p}^{(3)}=1.000$ \\
\hline
\end{tabular}

${ }^{\star}{ }^{\star}$ : Significant difference of $5.0 \%$. $\left.{ }^{\star \star}\right)$ : not possible to calculate due to the existence of information only on the group submitted to bariatric surgery. (1): using the Student t-test with unequal variance. (2): using the Student t-test with equal variance. (3): using the Fisher exact test. RV: reference value. 250HD: 25-hydroxy vitamin D. PTH: parathyroid hormone. BMD: bone mineral density. 


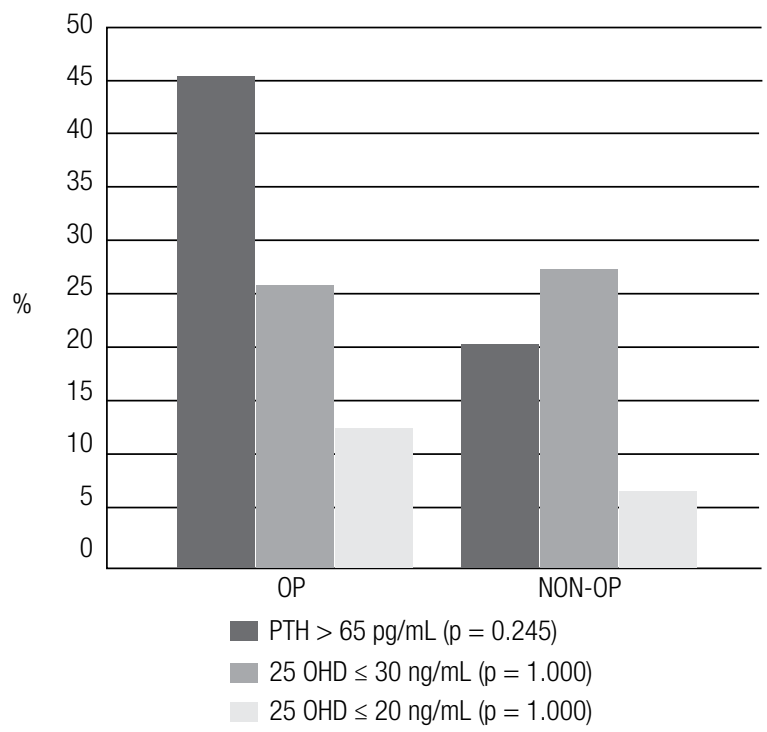

OP: operated on; NON-OP: non-operated on; 250HD: 25-hydroxy vitamin D; PTH: parathyroid hormone.

Figure 1. Secondary hyperparathyroidism and vitamin D deficiency in study patients.

Mean serum 25OHD in patients submitted to bariatric surgery who presented normal serum PTH was $41.13 \pm 6.13 \mathrm{ng} / \mathrm{mL}$, while for those who presented high levels of PTH $(>65 \mathrm{pg} / \mathrm{mL})$ it was $32.43 \pm 13.16$ $\mathrm{ng} / \mathrm{mL}(\mathrm{p}=0.147)$. Of the seven patients with high serum PTH in the surgery group, only 3 had serum $25 \mathrm{OHD}$ lower than $30 \mathrm{ng} / \mathrm{mL}$. In the non-surgical patients with normal and high serum $\mathrm{PTH}$, the mean serum $25 \mathrm{OHD}$ was $33.5 \pm 9.69$ and $34 \pm 6.56 \mathrm{ng} / \mathrm{mL}$, respectively $(\mathrm{p}=0.941)$.

Mean higher LS BMD was observed and lower values in the femoral neck and total femur in the group submitted to surgery, in comparison to the non-surgery group, but with no statistical significance $(\mathrm{p}=0.209)$ (Table 2$)$. Of the 15 surgical patients, $13(86.7 \%)$ presented a normal T-score, two (13.3\%) revealed low bone mass and no patients had osteoporosis according to World Health Organization criteria. One patient with low bone mass had normal serum PTH, AP and 25OHD, while the other had high serum PTH and AP with low 25OHD. Spine X-rays of the two patients with low bone mass did not reveal any fractures. Of the 14 patients in the group not submitted to surgery, 12 (85.7\%) presented normal T-scores, two (14.3\%) presented low LS BMD and no patients had osteoporosis. The two patients with low bone mass in this group had normal serum AP, PTH and 25OHD and one of these had a grade I fracture.
In relation to vertebral fractures, two patients from the surgery group $(13.3 \%)$ were found to have grade I morphometric fractures in the thoracic spine, and one patient from the non-surgery group $(7.14 \%)$ had a grade I fracture, also in the thoracic spine. The patient from the non-surgery group presented low LS BMD and normal serum 25OHD and PTH. The patients with fractures from the surgery group did not present any alterations in the serum PTH, 25OHD or BMD values.

\section{DISCUSSION}

Vitamin D deficiency, an inadequate intake of calcium and SHPT are common in obese individuals and have been described in previous studies $(4,6,7,8)$. The present study found a prevalence of $21.4 \%$ of SHPT and $28.6 \%$ of vitamin D deficiency in the morbidly obese patients with normal renal function and who had not been submitted to surgery which is similar to the data reported by a number of other authors $(6,7,9)$. The mean intake of calcium in the non-surgery group was less than $50 \%$ of the recommended levels for premenopausal women. The abovementioned metabolic alterations may intensify during the postoperative period and careful preoperative screening for alterations in bone metabolism and an adequate supplementation of vitamins and minerals are therefore essential to prevent or minimize osteometabolic complications that may occur after gastric bypass.

The mean calcium intake in the surgery group despite being significantly greater than in the non-surgery group was still lower than the recommended levels for such a specific group of patients, which should be between 1,000 and $1,800 \mathrm{mg} /$ day (4). The intake of vitamins D and B12 was also lower than the recommended levels. It may be inferred from these data that postoperative vitamin and mineral supplementation should not consist only of multivitamins, most of which do not contain the recommended daily requirements of calcium and vitamins D and B12.

The main absorption sites of calcium are the duodenum and the proximal jejunum, where the greatest concentration of calcium transporters is found. After gastric bypass, food intake no longer passes through these portions of the intestine, which may result in calcium deficiency. Associated with this, there is intolerance to foods rich in calcium, such as milk, and an absorption deficiency of vitamin $\mathrm{D}$ through the poor absorption of fat. Chronic poor absorption of calcium combined with 
inadequate supplementation may lead to SHPT and the individuals affected will have high serum PTH associated with normal or low serum calcium $(4,22,23)$. The fact that there is no significant difference between the mean $25 \mathrm{OHD}$ values in patients submitted to bariatric surgery with normal PTH and high PTH $(41.13 \pm 6.13$ vs. $32.43 \pm 13.16)$, and that only three of the seven patients with abnormal PTH levels had serum 25OHD less than $30 \mathrm{pg} / \mathrm{mL}$, suggests that vitamin $\mathrm{D}$ deficiency is not the main cause of SHPT in this group of patients and that the poor absorption of calcium appears to be a predominant factor for the development of SHPT.

Despite the lower calcium absorption, it is not common to find hypocalcemia in patients submitted to gastric bypass, probably due to the compensatory action of SHPT. In the present study, none of the patients submitted to bariatric surgery presented low serum calcium, as confirmed by data from other authors $(24,25)$, demonstrating that hypocalcemia is a low-sensitivity marker for evaluating bone disease in this population.

Youssef and cols. (24) conducted a prospective study with 193 morbidly obese women submitted to bariatric surgery and detected high serum PTH in 53.3\%, and vitamin D deficiency using a cutpoint of $<20 \mathrm{ng} / \mathrm{ml}$ in $20.2 \%$ (24). These findings are similar to those of the present study, with $46.6 \%$ of high PTH and $28.6 \%$ vitamin D deficiency $(<30 \mathrm{ng} / \mathrm{ml})$.

Pereira and cols. studied 39 women, 11 non-obese, 12 obese and 16 obese submitted to Roux-en-Y gastric bypass. They did not find any significant differences in serum AP, magnesium, PTH or 25OHD between the surgical, non-surgical and non-obese groups, which is in agreement with the results of the present study (26).

Several studies have negatively associated obesity with 25OHD status (27-31), including data that illustrate insufficient levels of up to $80 \%$ in obese individuals (32). One hypothesis is that vitamin D is stored by the fatty tissue of obese patients and that it may be gradually released into the circulation during weight loss (11). However, contrary to common belief, there is no significant improvement in 25OHD status after bariatric surgery, as illustrated by several longitudinal studies $(16,17,33-36)$. This was confirmed by the present study, in which no significant differences in the serum $25 \mathrm{OHD}$ levels were recorded in patients submitted to bariatric surgery. If vitamin $\mathrm{D}$ is released postoperatively from fatty tissue, the lack of high blood levels during this period appears to suggest that the steroid is being absorbed at even lower proportions.
In the present study, the time elapsed between surgery and the evaluation ranged from 7 to 22 months, and there were no significant differences between mean BMD and the prevalence of vertebral fractures in either group. It is possible that the relatively short duration of the study and the selection of eugonadic premenopausal women may have contributed to the bone sparing effect. Little data is available concerning the incidence or prevalence of fractures in patients submitted to bariatric surgery. In a recent 7-year study from Mayo Clinic presented at the $91^{\text {st }}$ Annual Meeting of the Endocrine Society a retrospective cohort of 97 patients submitted to bariatric surgery including men and pre- and postmenopausal women $90 \%$ of whom had undergone a gastric bypass, showed that the risk of a first fracture at any site was $1.8(1,1-2,8,95 \% \mathrm{CI})$ in patients submitted to bariatric surgery as compared with what would be expected for the general population for the same age (2l).

Some longitudinal studies have shown bone loss related to the degree of weight loss, but none of them specifically included premenopausal women $(2,11,13,26)$.

None of the patients with vertebral fractures submitted to surgery had low bone mass or osteoporosis, suggesting that bone fragility and increased risk of fracture were not exclusively related to bone mineral density in our group of patients.

The limitations of this study lie in the fact that it is a case series with a small sample. On the other hand, the selection of a specific group of premenopausal, eugonadic women made the analysis of bone metabolism alterations resulting from bariatric surgery more reliable since we excluded menopausal effects on bone health. More prospective studies are required to clarify the issue of bariatric surgery and bone loss.

In conclusion, the present study demonstrated that after Roux-en-Y gastric bypass there is evidence of poor absorption of calcium and vitamin D resulting in SHPT in a specific group of premenopausal, eugonadic women. Low serum 25OHD levels were not the main cause of SHPT, suggesting that the poor absorption of calcium could play a vital role. Close observation of nutritional aspects and bone density before and after bariatric surgery is essential to prevent or minimize metabolic complications.

Disclosure: no potential conflict of interest relevant to this article was reported.

\section{REFERENCES}

1. Haslam DW, James WPT. Obesity. Lancet. 2005;366:1197-209. 
2. Carrasco F, Ruz M, Rojas P, Csendes A, Rebolledo A, Codoceo J, et al. Changes in bone mineral density, body composition and adiponectin levels in morbidly obese patients after bariatric surgery. Obes Surg. 2009;19(1):41-6.

3. Whitlock G, Lewington S, Sherliker P, Clarke R, Emberson J, Halsey $\mathrm{J}$, et al. Body-mass index and cause-specific mortality in 900,000 adults: collaborative analyses of 57 prospective studies. Lancet. 2009;373(9669):1083-96.

4. Williams SE, Cooper K, Richmond B, Schauer P. Perioperative management of bariatric surgery patients: focus on metabolic bone disease. Cleve Clin J Med. 2008;75(5):333-49.

5. Ybarra J, Sánchez-Hernández J, Pérez A. Hypovitaminosis D and morbid obesity. Nurs Clin North Am. 2007;42(1):19-27.

6. Goldner WS, Stoner JA, Thompson J, Taylor K, Larson L, Erickson $J$, et al. Prevalence of vitamin D insufficiency and deficiency in morbidly obese patients: a comparison with non-obese controls. Obes Surg. 2008;18(2):145-50.

7. Hamoui N, Anthone G, Crookes PF. Calcium metabolism in the morbidly obese. Obes Surg. 2004;14(1):9-12.

8. Vilarrasa N, Maravall J, Estepa A, Sánchez R, Masdevall C, Navarro MA, et al. Low 25-hydroxyvitamin D concentrations in obese women: their clinical significance and relationship with anthropometric and body composition variables. J Endocrinol Invest. 2007;30(8):653-8.

9. Stein EM, Straint G, Sinha N, Ortiz D, Pomp A, MacMahon DJ, et al. Vitamin $D$ insufficiency prior to bariatric surgery: risk factors and a pilot treatment study. Clin Endocrinol (Oxf). 2009;71:176-83.

10. Wortsman J, Matsuoka LY, Chen TC, Lu Z, Holick MF. Decreased bioavailability of vitamin $\mathrm{D}$ in obesity. Am J Clin Nutr. 2000;72:690-3.

11. Fleischer J, Stein EM, Bessler M, Della Badia M, Restuccia N, Olivero-Rivera $\mathrm{L}$, et al. The decline in hip bone density after gastric bypass surgery is associated with extent of weight loss. J Clin Endocrinol Metab. 2008;93(10):3735-40.

12. Viégas MA, Bandeira L, Bandeira F. Complicações metabólicas da cirurgia bariátrica. In: Bandeira F, Graf H, Griz L, Faria M, LazarettiCastro M, eds. Endocrinologia e Diabetes. 2nd ed. Rio de Janeiro: Medbook; 2009. p. 1038-45.

13. Coates PS, Fernstrom JD, Fernstrom MH, Schauer PR, Greenspan SL. Gastric bypass for morbid obesity leads to an increase in bone turnover and a decrease in bone mass. J Clin Endocrinol Metab. 2004;89(3):1061-5.

14. Mahdy T, Atia S, Farid M, Adulatif A. Effect of Roux-en $Y$ gastric bypass on bone metabolism in patients with morbid obesity: Mansoura experiences. Obes Surg. 2008;18(12):1526-31.

15. Von Mach MA, Stoeckli R, Bilz S, Kraenzlin M, Langer I, Keller U. Changes in bone mineral content after surgical treatment of morbid obesity. Metabolism. 2004;53(7):918-21.

16. Abbasi AA, Amin M, Smiertka JK, Grunberger G, MacPherson B, Hares $M$, et al. Abnormalities of vitamin $D$ and calcium metabolism after surgical treatment of morbid obesity: a study of 136 patients. Endocr Pract. 2007;13(2):131-6.

17. Ybarra J, Sánchez-Hernández J, Gich I, De Leiva A, Rius X, Rodríguez-Espinosa $\mathrm{J}$, et al. Unchanged hypovitaminosis $\mathrm{D}$ and secondary hyperparathyroidism in morbid obesity after bariatric surgery. Obes Surg. 2005;15(3):330-5.

18. Compher CW, Badellino KO, Boullata JI. Vitamin D and the bariatric surgical patient: a review. Obes Surg. 2008;18(2):220-4.
19. Clements $\mathrm{RH}$, Yellumahanthi $\mathrm{K}$, Wesley $\mathrm{M}$, Ballem N, Bland KI. Hyperparathyroidism and vitamin $D$ deficiency after laparoscopic gastric bypass. Am Surg. 2008;74(6):469-74.

20. Carlin AM, Rao DS, Meslemani AM, Genaw JA, Parikh NJ, Levy S, et al. Prevalence of vitamin $D$ depletion among morbidly obese patients seeking gastric bypass surgery. Surg Obes Relat Dis. 2006;2(2):98-103.

21. Haglind EGC, Kennel KA, Collazo-Clavell ML, Achenbach SJ, Atkinson EJ, Melton JL, et al. Fracture risk after bariatric surgery. 91st Annual Meeting of the Endocrine Society, Washington DC, 2009; OR07-4.

22. Shah M, Simha V, Garg Abhimanyu. Review: long-term impact of bariatric surgery on body weight, comorbidities, and nutritional status. J Clin Endocrinol Metab. 2006;91(11):3223-4231.

23. DeMaria EJ. Bariatric surgery for morbid obesity. N Engl J Med. 2007;356(21):2176-83.

24. Youssef $Y$, Richards WO, Sekhar N, Kaiser J, Spagnoli A, Abumrad N, el al. Risk of secondary hyperparathyroidism after laparoscopic gastric bypass surgery in obese women. Surg Endosc. 2007;21(8):1393-6.

25. Diniz Mde F, Diniz MT, Sanches SR, Salgado PP, Valadão MM, Araújo FC, et al. Elevated serum parathormone after Roux-en-Y gastric bypass. Obes Surg. 2004;14(9):1222-6.

26. Pereira FA, de Castro JA, dos Santos JE, Foss MC, Paula FJ. Impact of marked weight loss induced by bariatric surgery on bone mineral density and remodeling. Braz $\mathrm{J}$ Med Biol Res. 2007;40(4):509-17.

27. Arunabh S, Pollack S, Yet J, Aloia JF. Body fat content and 25-hydroxyvitamin D levels in healthy women. J Clin Endocrinol Metab. 2003;88(1):157-61.

28. Kamycheva E, Sundsfjord J, Jorde R. Serum parathyroid hormone level is associated with body mass index. The 5th Tromso Study. Eur J Endocrinol. 2004;151(2):167-72.

29. Parikh SJ, Edelman M, Uwaifo GI, Freedman RJ, Semega-Janneh M, Reynolds $\mathrm{J}$, et al. The relationship between obesity and serum 1,25-dihydroxy vitamin D concentrations in healthy adults. J Clin Endocrinol Metab. 2004;89(3):1196-9.

30. Yanoff LB, Parikh SJ, Spitalnik A, Denkinger B, Sebring NG, Slaughter $P$, et al. The prevalence of hypovitaminosis $D$ and secondary hyperparathyroidism in obese Black Americans. Clin Endocrinol. 2006;64(5):523-9.

31. Snijder MB, van Dam RM, Visser M, Deeg DJ, Dekker JM, Bouter $\mathrm{LM}$, et al. Adiposity in relation to vitamin $\mathrm{D}$ status and parathyroid hormone levels: a population-based study in older men and women. J Clin Endocrinol Metab. 2005;90(7):4119-23.

32. Bischof MG, Heinze G, Vierhapper H. Vitamin D status and its relation to age and body mass index. Horm Res. 2006;66(5):211-5.

33. El-Kadre LJ, Rocha PRS, Tinoco AC, Tinoco RC. Calcium metabolism in pre- and post-menopausal morbidly obese women at baseline and after laparoscopic Roux-en-Y gastric bypass. Obes Surg. 2004;14(8):1062-6.

34. Johnson JM, Maher JW, DeMaria EJ, Downs RW, Wolfe LG, Kellum KM. The long-term effects of gastric bypass on vitamin $D$ metabolism. Ann Surg. 2006;243(5):701-4.

35. Sánchez-Hernández J,Ybarra J, Gich I, De Leiva A, Rius X, Rodríguez-Espinosa J, et al. Effects of bariatric surgery on vitamin $D$ status and secondary hyperparathyroidism: a prospective study. Obes Surg. 2005;15(10):1389-95.

36. Carlin AM, Rao DS, Yager KM, Genaw JA, Parikh NJ, Szymanski W. Effect of gastric bypass surgery on vitamin $D$ nutritional status. Surg Obes Relat Dis. 2006;2(6):638-42. 